possibly after they had come into contact with the Japanese, though some of the other heaps I have seen were undoubtedly raised by the Japanese themselves; in a few cases they appeared of quite recent accumulation.

Great stress is laid by Prof. Morse upon the platycnemic tibire found in the heap. But platycnemic tibix, as Prof. Milne well points out, are characteristic of the Aino race, and, I believe, though I cannot put my hand upon my authority, of other low-type existing peoples.

The "extraordinary blunder" the usual "Japanese gentleman" has with patriotic promptness reproved me for making I cannot notice, for I have not hitherto seen any statement or correction of it. But in saying that the eastern portion of the main island was probably peopled by an Aino race up to the fourteenth or fifteenth centuries, and in asserting that Yedo was not founded until the close of the sixteenth century, I was not strictly accurate. The most valuable information to be extracted from native works is to be got at by reading between the lines, and, following this system, I have for my own part arrived at the conclusion that, up to the thirteenth or fourteenth centuries at all events, the country east of the Rokugo River was peopled by a mixed Aino and Japanese race, whom I believe to have been the builders of the mounds. Ôta Dôkuwan erected a stronghold upon the site of the present castle of Yedo about the middle of the fifteenth century, but the Yedo Meisho (cited by Mr. McClatchie, in his paper on the Castle of Yedo, Tr. Asiat, Soc. Japan, vol. vi. part I) tells us that up to the end of the sjxteenth century it "was merely a small fortification" overlooking, doubtless, an inconsiderable town consisting of a mere aggregation of villages. Iyeyasu made it his capital about 1590 , and gave to the city the apt name of Yedo, or Door of the Rivers. What Prof. Morse means by charging me and "so many of" my "countrymen" with "the wilful blunder of calling the principal city of the empire by its wrong name" I cannot imagine. Does he find in the practice some covert "sneer" at things Japanese on the part of the "ordinary Briton"? Then is the "extra. ordinary American," who sheds upon Salem its due supply of zoological light, guilty of the same offence, for in his memoir he talks of "the bay of Yedo," "mans of Yedo," \&c. The fact is the expression "Tôkiô," invented by the successful party after the Revolution of 1868 , would have been unrecognisable by many readers of NATURE. Again, Yedo is a Japanese word, and is the name of the city; Tôkiô is a mispronounced Chinese compound, meaning " eastern capital," and is, properly, a mere official designation. So under the Shôguns Yedo was often called by various Chinese styles, but never lost its name of Yedo.

My belief that the mounds were swept away was founded upon a statement to that effect I saw in a Japanese newspaper since leaving Japan, after many years continuous residence, in January, 1879. But whether my belief was right or wrong, I fail to understand how its expression conld raise such ire in Salem. I sincerely trust that my inadvertence in not recognising the last plate of the memoir as a copper one will be forgiven.

Lastly, Prof. Morse complains of my review, as he terms my brief note on his memoir, being written in some "spirit" which he does not "now heed." This is deplorable, for it was written simply in the "spirit" of truth.

The question of cannibalism is discussed in Prof. Milne's paper in a most interesting manner. I would gladly give a résumé of his remarks on this portion of the subject, and answer some points I have left unnoticed both in the memoir and Prof. Morse's letter, but I fear that I have already trespassed terribly upon your space.

Arts Club, April, r880

The Destruction of Insect Pests by Application of Yeast

THE article on the destruction of insect pests, \&c., in NATURE, vol. xxi. p. 447 , by Mr. E. R. Lankester, contains statements upon which I beg to make some remarks :-

"Prof. Hagen has called attention to the old practice of destroying greenhouse pests by the application of yeast."

It is very interesting to me to hear that this is an old practice. I had never known it, and would be glad to receive any notice where it is published. In the many letters which I received since the publication of my pamphlet, nobody has mentioned that the use of yeast against greenhouse pests is a well-known remedy. Mr. Hovey, for fifty years the editor of the Magazine of Horticulture, assured me that he never heard of it. After it was suggested by me last year, the application of yeast has proved to be successful against Aphides.
" $\mathrm{He}$ imagines that the yeast-fungus enters the body of the insect on which it is sprinkled, and there produces a growth which is fatal to the insect-life."

For the experiment with potato-bugs, published in my paper, 100 beetles collected the same day and in the same place were divided into two parcels, and both kept in the same room. One parcel was sprinkled on three or four successive days, and most of those beetles died on the eighth day, the last one on the twelfth day. Of the other parcel all but three were alive and bright six weeks later, and more than 50 per cent. lived through the whole winter. I found in the dead ones, which had been sprinkled with diluted yeast, in the large sinus of the wings, spores of a fungus in quantity. The spores resembled those figured by Dr. M. Reess, ${ }^{\mathrm{I}}$ Plate I., Fig. ${ }^{15}, e d$, and were so numerous and so distinct that I could not have been deceived, the more as I am familiar with the anatomy of insects and with the blood-fluid and its contents. Not having studied, myself, fungi, I can only state that, after the beetles having died in a manner which showed manifestly an infection, I discovered cells in the blood-fluid which certainly are not to be found in the blood-fluid of unpoisoned insects, and which are similar to the figured ones.

It is a fact corroborated lately by Mr. A. Giard that a few spores of a poisonous fungus in a comparatively large quantity of water are sufficient to be propagated in caterpillars, which are sprinkled with such water. There is no doubt that a mashtub into which a diseased insect has once fallen will keep up a sufficient supply. Nevertheless when such spores are so common in mash that Dr. Bail, in using brewers' yeast, succeeded in numerous experiments, and that here the use of dry top-yeast, as well as the use of compressed bottom-yeast, gave the same successful results, I believe that it is of no particular avail to cultivate artificially Isaria spores in beer-mash. The recommendation to use simply yeast would be sufficient, and so it was given by myself : "The general result of the most accurate investigations of the beer-yeast fungus is entirely opposed to the notion that it can enter an insect's body and produce a disease." I am perfectly unable to find the publications alluder to, which, of course, would settle the question at once. Nothing in the size and the form of the spores would prevent them from entering the body.

The ingenious suggestion of a collection and cultivation of an insect's disease-producing fungus was made and published in I874 by Dr. John L. Leconte, from Philadelphia.

Cambridge, Mass.

H. A. HAGEN

\section{Recall of Sights and Tastes}

I THINK the following two facts, from my own personal experience, may be of some interest to Mr. Francis Galton.

I. In 1875 I was appointed by the Venezuelan Government to organise the library of the University in this city. The collection contained then about 8,000 different works, which I arranged and numbered on their backs, having no assistant but a servant for the rough part of the labour. Since that time I have been head librarian, it being my duty to be at the library on all mornings, Sundays excepted. It is natural that I should therefore know the place of every book on the shelves; but in the case of the more important works, as soon as the title is mentioned I am able to recall to my mind the exact appearance of the books, with their cosesponding numbers, the lettering being however much less distinct. It is no case of memory ; for I cannot say what book is to be found under a certain number; I must first have the image of the book, and afterwards I read its number, as if it were actually before my eyes. A considerable part of later additions to our library was numbered by the assistant librarian, as amongst these books there are but few which I can recall to my mind in the manner described.

2. In Mérida (a western state of Venezuela) the people use a substance called chimo (pronounce cheemó). It is made with the juice of tobacco, inspissated to the consistency of syrup, and mixed with powdered urao, cr sesquicarbonate of soda, from a small lagoon near the village of Lagunilla, not far from the town of Mérida. The chimo is black, and kept in small boxes made from the horns of cattle. When used a small quantity is put into the mouth outside the gums, where it is slowly dissolved by the saliva, and then swallowed down. Being myself pretty well accustomed to smoking cigars, I once felt desirous to try

I "Botanische Untersuchungen über die Alcoholgährungspilze," von Dr Max Reess. (Leipzig, 1870 .) 